\title{
ANALISIS PENGARUH KONSEP INTERIOR RUANG KERJA DI RUMAH TINGGAL PASCA PANDEMI COVID-19
}

\author{
Fivanda $^{1}$, Adi Ismanto ${ }^{2}$ \\ ${ }^{1}$ Program Studi Desain Interior, Universitas Tarumanagara \\ Email: fivanda@fsrd.untar.ac.id \\ ${ }^{2}$ Program Studi Desain Interior, Universitas Tarumanagara \\ Email: adii@fsrd.untar.ac.id
}

Masuk: 02-04-2021, revisi: 30-04-2021, diterima untuk diterbitkan : 30-04-2021

\begin{abstract}
Residential is an important means for humans. The house must be able to provide tranquility, comfort, and convenience. Before the Covid-19 pandemic spreads, function of residents was to provide shelter from hot sun and rain. Since March 2020, complying with the social physical distancing protocols has required many companies have to limit the number of employees working in the office. This means that work from office activities have not been fully implemented and the work from home policy is the choice of companies. Employees spend every day 10 hours working. It is necessary to have a workspace arrangement in a residence that can separate between work zones and rest zones. The purpose of this research is to describe how the influence of workspace design in residential houses for the efficiency and effectiveness of workers. Through the Post Evaluation Occupancy (POE) research method, the workspace in the 25 respondents' residence was used as a reference for evaluation by obtaining data through the Focus Group Discussion (FGD) process. With 3 respondents, direct observations were made and 22 respondents supported through a questionnaire. The evaluation results obtained show that $90 \%$ of workers need furniture to work, window for ventilation, lighting, and providing natural views. Visualized in the design concept 'less is more' that the implementation of a simple workspace but provides a physical and psychological experience to support working from home. A design concept that prioritizes the fulfillment of activities towards the function and use of furniture as needed.
\end{abstract}

Keywords: Work, furniture, interior, office, residential

\begin{abstract}
ABSTRAK
Rumah tinggal merupakan sarana penting bagi manusia. Pada perkembangannya rumah bukan hanya sekedar untuk menghindarkan diri dari hujan dan panas tetapi melainkan rumah harus mampu memberikan ketenangan, kesenangan bahkan kenyamanan. Sebelum pandemi Covid-19 merebak, fungsi rumah tinggal bagi penghuninya sebatas memberikan tempat perlindungan dari panas matahari dan cuaca dingin supaya terhindar dari hujan. Semenjak bulan Maret 2020, keharusan dalam mematuhi protokol social physical distancing mengharuskan perusahaan membatasi jumlah karyawan yang bekerja di kantor. Ini artinya, kegiatan work from office belum sepenuhnya dapat berjalan dan kebijakan work from home menjadi pilihan dari perusahaan-perusahaan. Mengingat waktu yang dihabiskan karyawan bekerja di kantor berkisar 10 jam per hari. Maka, diperlukan tatanan ruang kerja pada rumah tinggal yang nyaman serta dapat membedakan antara zona bekerja dengan zona beristirahat. Tujuan penelitian untuk memaparkan bagaimana pengaruh desain ruang kerja pada rumah tinggal terhadap efisiensi dan efektivitas pekerja dalam menjalankan perannya. Melalui metode penelitian Post Evaluation Occupancy (POE) ruang kerja pada rumah tinggal 25 responden dijadikan acuan sebagai bahan evaluasi dengan mendapatkan data naracoba pengguna melalui proses Focus Group Discussion (FGD). Dengan 3 responden, dilakukan pengamatan langsung dan 22 responden pendukung melalui kuesioner. Hasil evaluasi yang diperoleh dari naracoba menunjukan bahwa $90 \%$ pekerja membutuhkan furnitur untuk bekerja, ventilasi jendela sebagai penghawaan, pencahayaan, serta memberikan pemandangan alami. Divisualisasikan dalam konsep desain 'less is more' bahwa implementasi ruang kerja yang sederhana tetapi memberikan pengalaman secara fisik dan psikis yang mendukung kinerja work from home. Sebuah konsep desain yang mengutamakan pemenuhan aktivitas terhadap fungsi dan penggunaan furnitur sesuai kebutuhan.
\end{abstract}

Kata Kunci: Bekerja, furnitur, interior, kantor, rumah tinggal

\section{PENDAHULUAN}

Latar Belakang

Rumah tinggal merupakan sarana penting bagi manusia. Sebuah bangunan rumah tinggal terbentuk dari sebuah perencanaan serta perancangan arsitektur dan interior yang telah disesuaikan dengan 
aktivitas, keinginan dan kebutuhan penghuni (Karlem, 2007). Tetapi, pada perkembangannya rumah bukan hanya sekedar untuk menghindarkan diri dari hujan dan panas tetapi melainkan rumah harus mampu memberikan ketenangan, kesenangan bahkan kenyamanan bagi penghuninya. Sebelum terjadinya pandemi Covid-19 merebak, fungsi rumah tinggal bagi penghuninya hanya sebatas memberikan tempat perlindungan dari panas terik matahari dan dinginnya hujan. Rumah yang nyaman tidak perlu mewah karena rumah yang nyaman adalah rumah yang bisa memenuhi kebutuhan dan aktivitas penghuninya terutama sekarang ini semua hal harus dapat dilakukan didalam rumah. Manusia sebagai pengguna dan penghuni rumah tinggal biasanya hanya berada dalam rumah tinggal selama tidak lebih dari 12 jam dengan kondisi dimana penggunanya bekerja di kantor, dan lebih banyak melakukan aktivitas di luar rumah. Manusia rata-rata memerlukan waktu tidur 7-8 jam per hari serta 2-4 jam per hari untuk kegiatan bekerja di rumah, makan, berpakaian, bersantai yang semua dilakukan di dalam rumah. Tetapi, untuk masa sekarang kegiatan work from office belum sepenuhnya dapat berjalan dan kebijakan work from home menjadi pilihan dari perusahaan-perusahaan. Dari beberapa penelitian yang sudah dilakukan dan dipahami dari Jurnal ilmiah psikologi oleh Andriani (2009) mengenai desain ruang kerja, privasi dan tekanan. Memaparkan mengenai pengaruh desain ruang kerja rancangan terbuka dan privasi terhadap tekanan. Karyawan yang menempati suatu ruang tertentu dengan variabel desain ruang kerja dan privasi. Tim peneliti mendapatkan pengembangan penelitian menjadi pengaruh konsep interior ruang kerja dalam rumah tinggal dalam artian perancangan interior atau ruang merupakan bagian penting dalam suatu bangunan rumah tinggal, karena sebagian besar aktivitas manusia terjadi di dalamnya. Di dalam rumah tinggal juga akan terjadi interaksi antara elemen interior dengan aktivitas, perilaku, suasana hati penghuni di dalamnya. Elemen interior seperti lantai, dinding, plafon, dan furnitur yang ada di dalamnya ditata sedemikian rupa dengan prinsip desain yang memanfaatkan variasi pilihan warna, material, tekstur, dan pencahayaan serta penghawaan.

\section{METODE PENELITIAN}

Penelitian ini menggunakan data primer yang merupakan hasil pengumpulan data dari observasi terhadap data fisik objek penelitian dan wawancara responden melalui kuesioner yang berkaitan dengan ruang kerja pada rumah tinggal. Sedangkan data sekunder merupakan data yang didapat dari berbagai referensi pustaka. Melalui metode penelitian Post Evaluation Occupancy (POE) ruang kerja pada rumah tinggal sejumlah 25 responden dijadikan acuan sebagai bahan evaluasi. Berdasarkan data dari naracoba pengguna tersebut dilakukan proses Focus Group Discussion (FGD). Metode analisis sistemik melalui evaluasi pasca penggunaan atau Post Occupancy Evaluation (POE) didefinisikan oleh Zimring dan Reizenstein (dikutip dalam Zimring, 2013) sebagai pengujian efektivitas sebuah lingkungan buatan bagi kebutuhan manusia. Evaluasi pasca penggunaan ini mengandalkan kebutuhan atau program pengguna sebagai kriteria atau tolak ukur keberhasilan suatu penataan lingkungan buatan melalui persepsi pengguna dalam hal ini adalah pengguna ruang kerja dalam rumah tinggal.

\section{HASIL DAN PEMBAHASAN}

Hasil dan pembahasan penelitian ini diantaranya didapatkan dari observasi lapangan oleh tim peneliti pada ruang kerja masing-masing yang hasilnya didiskusikan secara daring melalui platform google meet pada tanggal 15 Desember 2020. Observasi lapangan dengan 3 responden penelitian berlokasi di 3 kota yaitu Jakarta, Tangerang, dan Bandung. Selain itu dilakukan wawancara dengan kuesioner kepada 22 orang responden yang melakukan kegiatan work from home sebagai data pendukung. Hasil observasi dan hasil kuesioner pasca huni bekerja dari rumah tersebut dilakukan mulai 10 Desember hingga 20 Desember 2020 untuk mengetahui bagaimana dampak fisik dan psikis, serta kebutuhan suatu desain interior ruang atau area kerja dari pasca 
bekerja dari rumah. Keseluruhan analisis dan proses perancangan interior berikut ini mengacu pada Kilmer dan Kilmer (2014).

\section{Identifikasi Objek Penelitian \\ Deskripsi Umum}

Nama Proyek

Sasaran

Status proyek

: Ruang kerja pada rumah tinggal

Pemilik

: Seluruh pengguna fasilitas tidak dibatasi usia

Lokasi

: Nyata

\section{Deskripsi Khusus}

Tipe Rumah Tinggal : Cluster / komplek perumahan tipikal

Kegiatan

: Melakukan kegiatan work from home dengan berkisar 10-12 jam sehari

\section{Analisis Bangunan dan Ruang}

\section{Objek penelitian responden 1}

Rumah tinggal responden 1 berlokasi di wilayah Jakarta Utara yang merupakan komplek perumahan cluster. Memiliki luas bangunan $180 \mathrm{~m}^{2}$ dan memiliki 2 lantai. Sehingga area kerja berukuran $1.5 \times 2 \mathrm{~m}^{2}$ terletak di lantai 2 berdekatan dengan jendela dan pintu menuju balkon lantai 2. Orientasi bangunan menghadap ke Selatan sehingga pada siang hari cukup mendapatkan pencahayaan alami dari jendela.

\section{Gambar 1.}

\section{Ruang Kerja Responden 1}
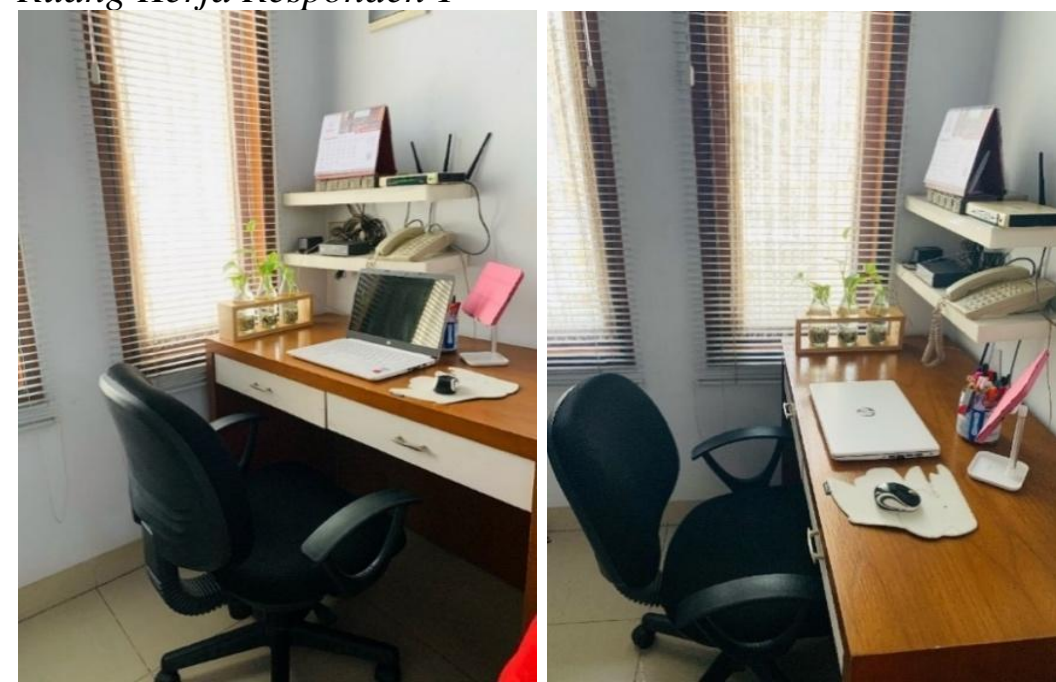

Sumber: Tim peneliti, (2020)

Jendela berukuran 80 × 150 m membatasi ruang dalam dengan bagian luar (balkon/teras) yang menghadap ke jalan di dalam perumahan tersebut. Untuk penghawaan menggunakan penghawaan buatan yaitu penyejuk udara dan juga didukung penghawaan alami melalui bukaan pintu dan jendela di sisi kirinya. Sirkulasi udara pada area ini cukup baik. Area kerja ini tidak disekat oleh dinding tetapi menyatu dengan ruang baca serta ruang bersantai. Pada area ini hanya terdiri dari area kerja dan 2 kamar tidur pada sisi membelakangi area kerja ini. Ruangan interior ini menggunakan material lantai dari keramik berukuran 60x60 cm, dinding dari bata hebel finishing cat dinding berwarna putih dan plafon setinggi 4 meter dari material berbahan gypsum dengan finishing cat dinding warna putih senada. Untuk pencahayaan buatan dengan tambahan armatur 
downlight jenis lampu PL daylight sebanyak 4 titik lampu. Keseluruhannya pengguna merasa nyaman selama bekerja kurang lebih 10 bulan pada area ini dikarenakan adanya jendela yang sangat membantu memberikan dampak fisik dan psikis yang baik. Pengguna tidak mudah merasa lelah dan tetap dapat berkonsentrasi dengan baik. Pada pagi hari hingga siang hari mendapatkan pencahayaan dan pemandangan alami sehingga walaupun bekerja dirumah dapat merasakan interaksi secara tidak langsung dengan lingkungan luar. Kekurangannya hanya pada tata akustik dikarenakan area tidak disekat oleh dinding menjadi sebuah ruang kerja. Terutama bagi responden 1 yang berprofesi sebagai dosen dalam melakukan perkuliahan. Perlu konsentrasi penuh pada saat ada aktivitas lain yang dilakukan pengguna lain pada sekitar area ini.

\section{Objek penelitian responden 2}

Rumah tinggal responden 2 berlokasi di wilayah Bintaro kota Tangerang Selatan yang merupakan komplek perumahan cluster. Profesi responden 2 sebagai dosen sekaligus praktisi desainer interior. Bangunan rumah tinggal seluas $58 \mathrm{~m}^{2}$ dan luas tanah $112 \mathrm{~m}^{2}$ merupakan bangunan 1 lantai. Ruang kerja berukuran $1.2 \times 1 \mathrm{~m}^{2}$ terletak di lantai 1 pada kamar tidur berdekatan dengan jendela yang menghadap ke taman belakang rumah. Orientasi bangunan menghadap ke Utara sehingga pada siang hari cukup mendapatkan pencahayaan alami dari jendela. Pada siang hari pengguna hanya menggunakan lampu meja dan lampu pada ambalan. Jendela berukuran 100 x $180 \mathrm{~m}$ tersebut membatasi ruang dalam dengan taman belakang pada rumah tinggal tersebut. Mengacu pada Mungkasa (2020), untuk penghawaan menggunakan penghawaan buatan dan juga didukung penghawaan alami melalui bukaan pintu dan jendela di sisi kirinya. Area kerja memang terdapat dalam kamar tidur sehingga fungsi kamar tidur ini tidak hanya digunakan untuk beristirahat tetapi untuk digunakan pengguna menghabiskan waktunya lebih dari 10 jam sehari bekerja.

Gambar 2.

\section{Ruang Kerja Responden 2}
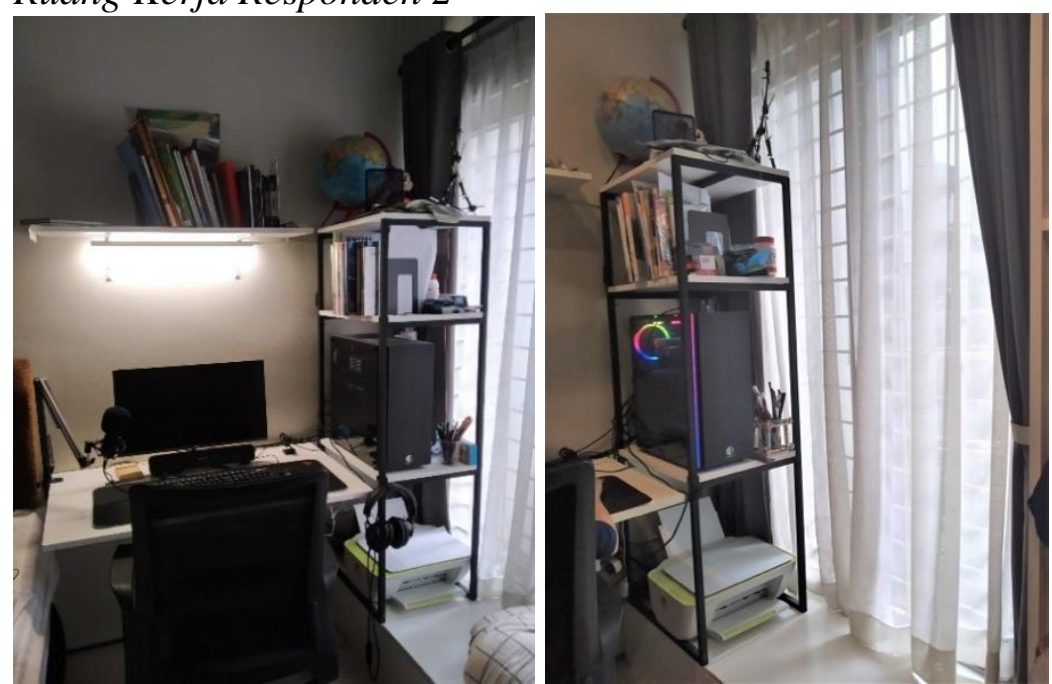

Sumber: Tim peneliti, (2020)

Ruangan interior ini menggunakan material lantai dari keramik berukuran $30 \times 30 \mathrm{~cm}$, dinding dari bata hebel finishing cat dinding berwarna putih dan plafon setinggi 3 meter dari material berbahan gypsum dengan finishing cat dinding warna putih. Spesifikasi material ini mengacu pada Suptandar (2003). Untuk pencahayaan buatan dengan tambahan armatur downlight jenis lampu PL pencahayaan daylight sebanyak 2 titik lampu. Keseluruhannya pengguna merasa nyaman selama bekerja pada area ini dikarenakan adanya jendela yang sangat membantu memberikan dampak fisik dan psikis yang baik. Pada pagi hingga siang hari mendapatkan pencahayaan dan 
pemandangan alami sehingga walaupun bekerja dirumah dapat merasakan interaksi secara tidak langsung dengan lingkungan luar. Kekurangannya dikarenakan posisi ruang kerja ini berada di bagian belakang dari bangunan rumah tinggal. Sehingga, apabila cuaca diluar mendung pencahayaan alami dalam ruang menjadi lebih redup.

\section{Objek Penelitian Responden 3}

Rumah tinggal responden 3 yang berlokasi di kota Bandung, Jawa Barat yang merupakan komplek perumahan cluster. Memiliki luas bangunan $119 \mathrm{~m}^{2}$ dan memiliki 2 lantai. Sehingga area kerja berukuran $2 \times 2.5 \mathrm{~m}^{2}$ terletak di lantai 1 pada sisi samping bangunan rumah tinggal yang berbentuk L. Orientasi bangunan menghadap ke Selatan sehingga pada siang hari cukup mendapatkan pencahayaan alami dari jendela. Pengguna berprofesi sebagai dosen yang memiliki hobi yang cukup bervariasi sehingga ruang hobi ini sejak bulan Maret 2020 yang lalu dimanfaatkan juga sebagai ruang kerja. Memiliki jendela berukuran 100 x $150 \mathrm{~m}$ tersebut membatasi ruang dalam dengan bagian luar yaitu balkon (teras) samping bangunan lantai 1.

\section{Gambar 3.}

\section{Ruang Kerja Responden 3}
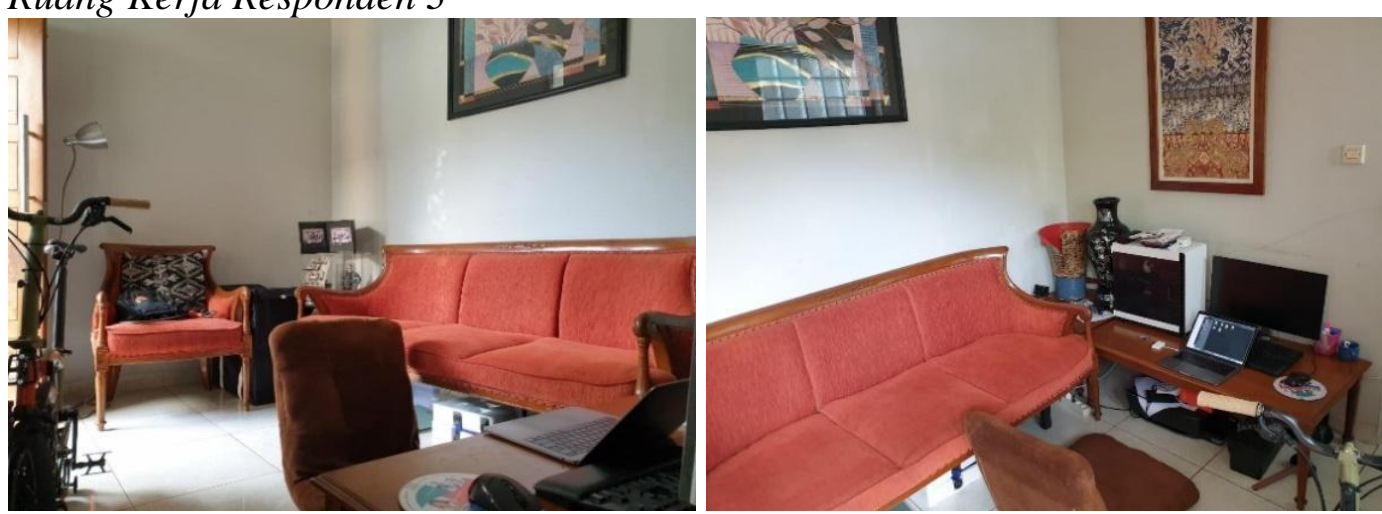

Sumber Gambar: Tim peneliti, (2020)

Untuk penghawaan menggunakan penghawaan alami karena iklim tropis dan sejuk dari kota Bandung. Perumahan terletak di komplek perbukitan dan jauh dari kebisingan kota. Penghawaan alami melalui bukaan pintu dan jendela di sisi kirinya. Sirkulasi udara pada area ini sangat baik. Area kerja disekat oleh dinding sehingga menyatu dengan ruang ruang bersantai. Ruangan interior ini menggunakan material lantai dari keramik berukuran $40 \times 40 \mathrm{~cm}$, dinding dari bata hebel finishing cat dinding berwarna putih dan plafon setinggi 3 meter dari gypsum finishing cat dinding warna putih. Untuk pencahayaan buatan dengan tambahan armatur downlight jenis lampu PL daylight sebanyak 2 titik lampu. Pengguna merasa nyaman selama bekerja pada area ini dikarenakan adanya pintu dan jendela yang memberikan pemandangan alami sehingga tidak cepat merasa lelah saat bekerja. Perancangan demikian ini mengacu pada studi Purwanto (2020), pada pagi hingga siang hari mendapatkan pencahayaan dan pemandangan alami sehingga walaupun bekerja di rumah dapat merasakan interaksi secara tidak langsung dengan lingkungan luar. Apabila pengguna merasa bosan, pengguna dapat melakukan hobinya seperti menyusun miniatur bangunan dan pesawat. Keseimbangan fisik dan psikis sangat berpengaruh pada kinerja dan efektivitas konsentrasi responden 3 .

\section{Analisis dan Hasil Observasi Pengguna, Aktivitas dan Fasilitas Kebutuhan}

Berdasarkan observasi bangunan dan ruang yang terdiri dari 3 objek penelitian masing-masing memiliki karakteristik pengguna mulai dari jenis kegiatan, profesi, hobi, warna kesukaan sampai dengan kebutuhan furnitur dan elemen estetis yang berbeda (tabel 1): 
Tabel 1.

Analisis Pengguna, Aktivitas dan Fasilitas Kebutuhan 3 Objek Penelitian

Sumber: Tim peneliti, (2020)

\begin{tabular}{|c|c|c|c|c|}
\hline No & Responden & Aktivitas Bekerja & $\begin{array}{l}\text { Furniture \& Elemen } \\
\text { Estetis (eksisting) }\end{array}$ & $\begin{array}{l}\text { Kebutuhan Furnitur } \\
\text { \& Elemen Estetis }\end{array}$ \\
\hline 1. & $\begin{array}{l}\text { Responden } 1 \\
\text { Jenis Kelamin: Perempuan } \\
\text { Usia : } 36 \text { Tahun } \\
\text { Profesi : Dosen dan } \\
\text { Desainer Interior } \\
\text { Lama waktu bekerja : > } 10 \\
\text { jam } \\
\text { Warna Favorit : putih }\end{array}$ & $\begin{array}{l}\text { 1. Mengajar daring } \\
\text { 2. Menggambar } \\
\text { desain ruang } \\
\text { secara manual dan } \\
\text { digital } \\
\text { 3. Menulis dan } \\
\text { membaca } \\
\text { 4. Koreksi tugas } \\
\text { gambar } \\
\text { 5. Ruang gerak } \\
\text { terhadap aktivitas } \\
\text { sudah cukup baik }\end{array}$ & $\begin{array}{l}\text { - Meja 100x60x75 cm } \\
\text { - Kursi kerja } \\
\text { 50x50x100 cm } \\
\text { - Tidak ada lampu meja } \\
\text { - Tidak ada lemari } \\
\text { penyimpanan } \\
\text { - Tidak ada artwork }\end{array}$ & $\begin{array}{l}\text { Meja } \\
\text { Kursi kerja } \\
\text { Lampu meja (Artwork) } \\
\text { Lemari buku }\end{array}$ \\
\hline 2. & $\begin{array}{l}\text { Responden } 2 \\
\text { Jenis Kelamin : Laki-laki } \\
\text { Usia : } 40 \text { Tahun } \\
\text { Profesi : Dosen dan } \\
\text { Praktisi Desainer Interior } \\
\text { Lama waktu bekerja : > } 10 \\
\text { jam } \\
\text { Warna Favorit: hitam, } \\
\text { putih, biru tua, abu-abu }\end{array}$ & $\begin{array}{l}\text { 1. Mengajar daring } \\
\text { 2. Menulis dan } \\
\text { membaca } \\
\text { 3. Mengkoreksi } \\
\text { tugas gambar } \\
\text { 4. Menggambar } \\
\text { desain interior } \\
\text { ruang }\end{array}$ & $\begin{array}{l}\text { - Meja berbentuk } \\
\text { ambalan 90x50x75cm } \\
\text { - Kursi kerja } \\
50 \times 60 \times 120 \mathrm{~cm} \\
\text { - Rak 80x40x } 100 \mathrm{~cm} \\
\text { - Artwork: } \\
\text { miniatur }\end{array}$ & $\begin{array}{l}\text { Meja } \\
\text { Kursi kerja } \\
\text { Lampu meja (Artwork) } \\
\text { Lemari buku }\end{array}$ \\
\hline 3. & $\begin{array}{l}\text { Responden } 3 \\
\text { Jenis Kelamin : Laki-laki } \\
\text { Usia : } 62 \text { Tahun } \\
\text { Profesi : Dosen dan } \\
\text { Praktisi Desainer Interior } \\
\text { Lama waktu bekerja : > } 10 \\
\text { jam } \\
\text { Warna Favorit: hijau army. }\end{array}$ & $\begin{array}{l}\text { 1. Mengajar daring } \\
\text { 2. Menulis dan } \\
\text { membaca } \\
\text { 3. Mengkoreksi } \\
\text { tugas dan ujian }\end{array}$ & $\begin{array}{l}\text { - Meja 90x50x50cm } \\
\text { - Kursi kerja model } \\
\text { tatami 50x50x50cm } \\
\text { - Artwork: } \\
\text { lukisan,miniatur }\end{array}$ & $\begin{array}{l}\text { Meja } \\
\text { Kursi kerja } \\
\text { Lemari buku } \\
\text { Artwork: lukisan, } \\
\text { lampu meja }\end{array}$ \\
\hline
\end{tabular}

\section{Kuesioner Evaluasi Ruang Kerja di Rumah Tinggal Pada Masa Pandemi Covid-19 (Work From Home)}

Sejumlah 22 kuesioner dibagikan dan diisi secara online kepada masing-masing pengguna yang bekerja di ruang kerjanya masing-masing pada saat pandemi untuk mendapatkan tanggapan terhadap kondisi ruang kerjanya. Pengisian dilakukan secara daring dan menginformasikan kondisi ruang kerja serta evaluasi aktivitas yang dilakukan (tabel 2).

Tabel 2.

Hasil Kuesioner Evaluasi Ruang Kerja di Rumah Tinggal

Sumber tabel: Tim peneliti, 2020

\begin{tabular}{llll}
\hline No & Pertanyaan & Jawaban & Persentase \\
\hline 1. & Usia Responden & $20-30$ & $46 \%$ \\
& & $31-50$ & $31 \%$ \\
& & $>50$ & $23 \%$ \\
\hline 2. & \multirow{2}{*}{ Jenis Kelamin } & Laki-laki & $54 \%$ \\
& & Perempuan & $46 \%$ \\
\hline
\end{tabular}




\begin{tabular}{|c|c|c|c|}
\hline 3. & $\begin{array}{l}\text { Profesi } \\
\text { (boleh pilih lebih dari } 1 \\
\text { jawaban) }\end{array}$ & $\begin{array}{l}\text { Dosen/Akademisi } \\
\text { Desainer Interior } \\
\text { Desainer Grafis } \\
\text { Freelance Desainer } \\
\text { Wirausaha }\end{array}$ & $\begin{array}{l}38 \% \\
61 \% \\
8 \% \\
15 \% \\
15 \%\end{array}$ \\
\hline 4. & $\begin{array}{l}\text { Pada masa pandemi } \\
\text { Covid-19, berapa jam yang } \\
\text { Anda habiskan untuk } \\
\text { bekerja di rumah per-hari? }\end{array}$ & $\begin{array}{l}<10 \text { jam } \\
=10 \text { jam } \\
>10 \text { jam }\end{array}$ & $\begin{array}{l}46 \% \\
13 \% \\
39 \%\end{array}$ \\
\hline 5. & $\begin{array}{l}\text { Kebutuhan Furniture apa } \\
\text { yang anda butuhkan saat } \\
\text { bekerja dirumah? } \\
\text { (boleh pilih lebih dari } 1 \\
\text { jawaban) }\end{array}$ & $\begin{array}{l}\text { Meja Kerja } \\
\text { Kursi Kerja } \\
\text { Meja Gambar } \\
\text { Lemari } \\
\text { Laptop } \\
\text { Rak terbuka }\end{array}$ & $\begin{array}{l}92 \% \\
100 \% \\
0 \% \\
50 \% \\
8 \% \\
8 \%\end{array}$ \\
\hline 6. & $\begin{array}{l}\text { Warna favorit untuk ruang } \\
\text { kerja? }\end{array}$ & $\begin{array}{l}\text { Muda/Terang } \\
\text { Sedang/Semi Gelap } \\
\text { Tua/Gelap }\end{array}$ & $\begin{array}{l}90 \% \\
10 \% \\
0 \%\end{array}$ \\
\hline 7. & $\begin{array}{l}\text { Apakah Anda memiliki } \\
\text { artwork untuk } \\
\text { kenyamanan bekerja di } \\
\text { rumah? }\end{array}$ & $\begin{array}{l}\text { Ya } \\
\text { Tidak }\end{array}$ & $\begin{array}{l}23 \% \\
77 \%\end{array}$ \\
\hline 8. & $\begin{array}{l}\text { Apakah tata letak ruang } \\
\text { kerja anda saat bekerja } \\
\text { dirumah sudah nyaman? }\end{array}$ & $\begin{array}{l}\text { Ya } \\
\text { Tidak } \\
\text { Mungkin }\end{array}$ & $\begin{array}{l}61 \% \\
31 \% \\
8 \%\end{array}$ \\
\hline 9. & $\begin{array}{l}\text { Menurut anda, seperti apa } \\
\text { kriteria ruang kerja yang } \\
\text { Ideal di rumah ? } \\
\text { (boleh pilih lebih dari } 1 \\
\text { jawaban) }\end{array}$ & $\begin{array}{l}\text { Terdapat Jendela } \\
\text { Ergonomis } \\
\text { Bersih/Rapih } \\
\text { Utilitas yang baik } \\
\text { (cahaya/akustik/penghawaan). } \\
\text { Furniture } \\
\text { (meja/kursi/lemari/ } \\
\text { rak) }\end{array}$ & $\begin{array}{l}90 \% \\
100 \% \\
15 \% \\
100 \% \\
100 \%\end{array}$ \\
\hline
\end{tabular}

Berdasarkan hasil kuesioner dan wawancara dengan pengguna ruang kerja selama masa pandemi yang disebarkan kepada responden dapat ditarik kesimpulan bahwa keseluruhan pengguna hanya membutuhkan area kerja yang memiliki jendela dan furnitur pendukung bekerja yaitu meja kerja, kursi kerja dan lemari penyimpanan. Hal ini dirancang berdasarkan acuan dari Postel (2020). Untuk artwork hanya minoritas pengguna yang membutuhkan. Ventilasi dengan jendela pada ruang kerja memegang peranan penting dalam meningkatkan produktivitas dan kestabilan kinerja para pekerja yang bekerja dari rumah. Posisi jendela yang ideal bersebelahan dengan ruang kerja atau di depan area kerja. Kalau posisi jendela membelakangi area kerja, biasanya kurang mendukung untuk pekerjaan daring yang membutuhkan tampilan wajah yang jelas pada saat sedang video conference.

\section{Konsep Perancangan Interior (Hasil Evaluasi Pasca Penggunaan dan Evaluasi Kuesioner)}

Berdasarkan hasil analisis dan evaluasi pengguna melalui kuesioner dan observasi ruang kerja yang digunakan selama masa pandemi Covid-19, didapatkan hasil bahwa konsep 'new normal' ruang dan area kerja di rumah tinggal dapat tercipta hanya dengan mengatur ulang tata letak dan konsep desain. Secara sederhana, pengguna hanya membutuhkan furnitur standar untuk bekerja dan ventilasi jendela sebagai penghawaan, pencahayaan serta memberikan pemandangan alami kepada pekerja. Para pekerja tidak akan cepat merasa kelelahan bahkan bekerja lebih dari 10 jam per hari. Sehingga tim peneliti melakukan penyusunan konsep perancangan interior ruang kerja 
pada rumah tinggal melalui mood board (gambar 4). Keseluruhan tahapan ini mengacu pada BottiSalitsky (2017).

Konsep desain bertema 'less is more' memperlihatkan bahwa implementasi ruang kerja menjadi lebih sederhana dapat memberikan pengalaman lebih kepada pengguna. Pengalaman secara fisik dan psikis yang mendukung kinerja work from home (Cunliffe, 2000). Elegan dan nyaman dari ruang kerja didapat dari perpaduan yang selaras antara nuansa modern pada rumah tinggal dengan kesederhanaan penataan ruang atau area kerja. Penggunaan warna netral seperti putih, hitam, abuabu serta warna natural memberikan nilai estetika tersendiri. Penggunaan warna ini mengacu pada Asensio (2003) dan Moore (2004).

\section{Gambar 4.}

Mood board Perancangan Ruang Kerja Rumah Tinggal

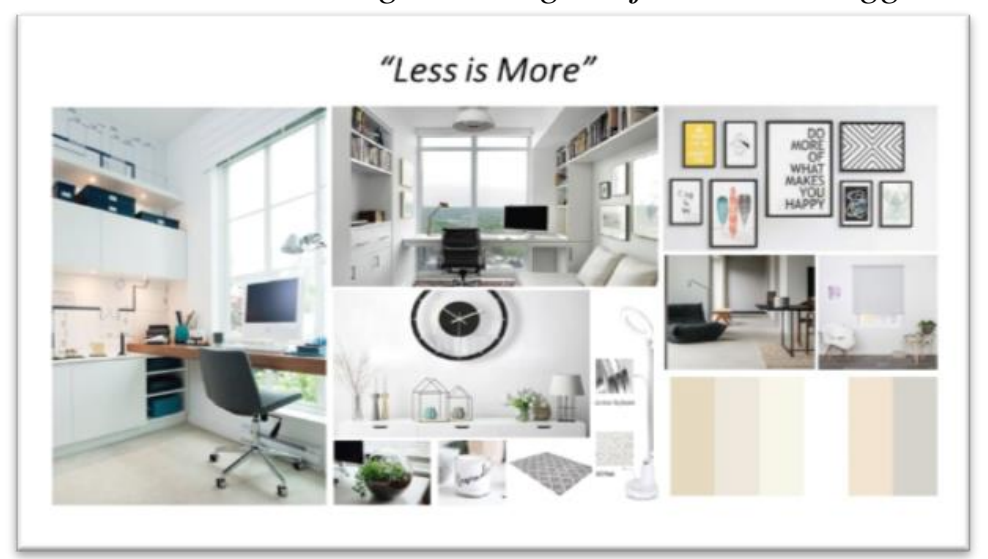

Sumber: Tim peneliti, (2020)

Gambar 5.

Layout Furnitur Perancangan Ruang Kerja di Rumah Tinggal

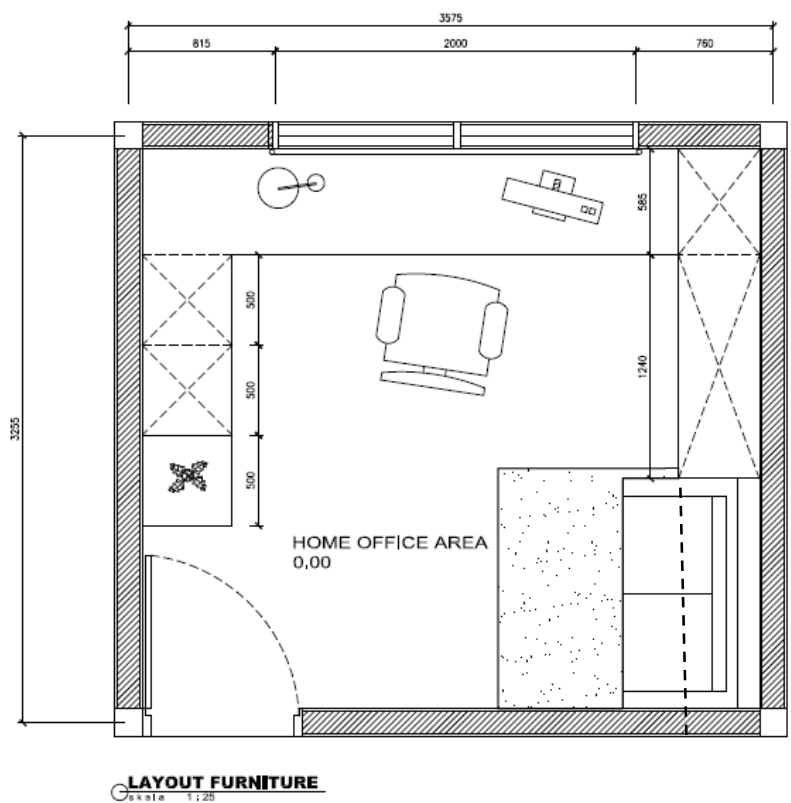

Sumber Gambar: Tim peneliti, (2020) 


\section{Hasil Desain}

Hasil desain di bawah ini merupakan lanjutan dari konsep acuan rancangan desain interior ruang kerja. Kebutuhan furnitur standar yang diperlukan apabila ruangan berbentuk persegi dengan luas 3-9 $\mathrm{m}^{2}$ hanya perlu penataan meja, kursi, rak penyimpanan yang teratur serta terorganisir dengan baik.

Gambar 6.

View 1 - Ruang Kerja

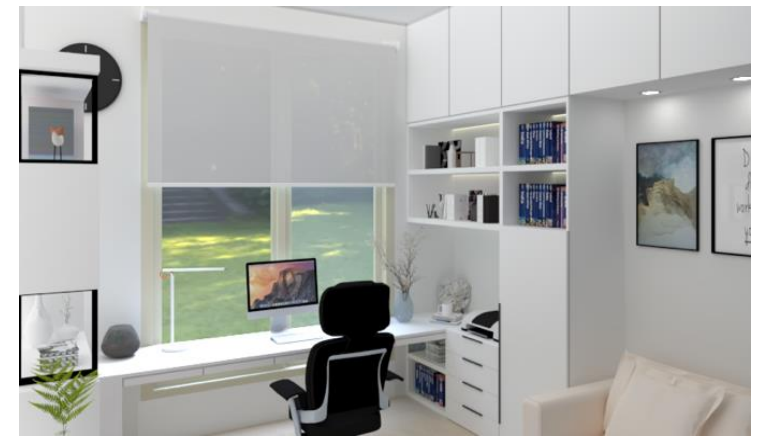

Gambar 8.

View 3 - Ruang Kerja

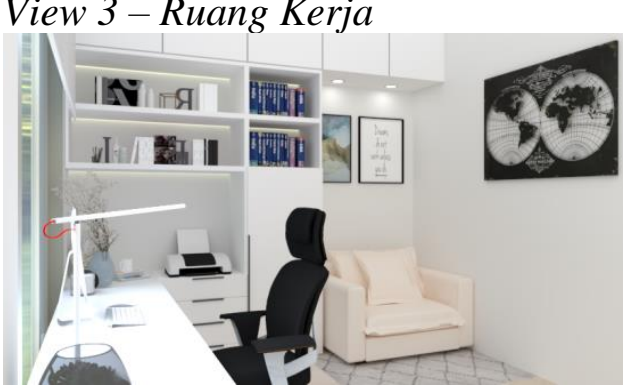

Sumber: tim Peneliti, (2020)

\section{Gambar 7.}

View 2 - Ruang Kerja

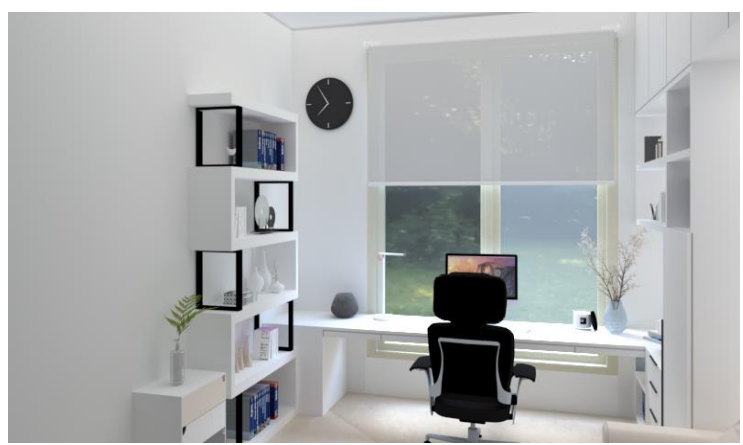

Posisi meja idealnya diletakkan di samping atau di depan jendela sehingga cahaya dan sirkulasi udara serta pemandangan indah dapat mudah terlihat oleh pengguna. Sistem penghawaan buatan dengan penyejuk udara dan pencahayaan selain secara alami juga dapat menggunakan downlight jenis lampu PL 10-12 watt. Furnitur yang paling penting digunakan adalah kursi kerja yang sudah memenuhi standar ergonomis sehingga tidak menimbulkan gangguan kesehatan fisik. Pengukuran untuk meja kerja dan lemari penyimpanan dapat disesuaikan dengan luas area atau ruang kerja yang dimiliki (gambar 6, 7, dan 8). Artwork sebagai elemen estetik tetap dapat digunakan tergantung dari kebutuhan biaya yang dapat ingin dikeluarkan oleh masing-masing pengguna. Artwork tersebut salah satunya lampu meja, lukisan, tulisan quote yang menginspirasi, jam dinding, tanaman. Peletakkan sofa dapat menjadi alternatif bagi pengguna untuk beristirahat sejenak apabila sudah merasa kelelahan.

\section{KESIMPULAN DAN SARAN}

Berdasarkan hasil observasi, wawancara dan kuesioner serta diskusi terarah dapat disimpulkan bahwa konsep perancangan interior ruang kerja pada rumah tinggal sudah tidak sama pasca pandemi Covid-19. Sebelumnya ruang kerja di rumah tinggal bukan merupakan kebutuhan utama. Tetapi dikarenakan manusia lebih banyak menghabiskan waktu bekerja di luar rumah seperti di kantor. Konsep new normal ruang kerja dirumah tinggal memiliki persepsi yang sama dengan pekerja yang biasanya bekerja di perkantoran. Konsep new normal pada ruang dan area kerja di rumah tinggal dapat tercipta hanya dengan mengatur ulang tata letak dan konsep desain. Secara sederhana pengguna hanya membutuhkan furnitur untuk bekerja dan ventilasi jendela sebagai 
penghawaan, pencahayaan serta memberikan pemandangan alami kepada pekerja. Konsep desain bertema 'less is more' memperlihatkan bahwa implementasi ruang kerja menjadi lebih sederhana dapat memberikan pengalaman lebih kepada pengguna. Pengalaman secara fisik dan psikis yang mendukung kinerja work from home. Pengguna lebih mudah fokus berkonsentrasi dan tidak mudah kelelahan. Dengan perpaduan warna dan material netral seperti hitam, putih, abu-abu serta coklat sebagai aksentuasi yang selaras antara nuansa modern pada rumah tinggal dengan kesederhanaan penataan ruang atau area kerja. Penggunaan artwork sebagai elemen estetik sebagai pelengkap ruang kerja seperti lampu meja, lukisan, miniatur, tanaman artificial maupun non-artificial. Konsep tema sederhana dan bersih serta sentuhan elegan menjadi pilihan utama dari ruang kerja ini.

\section{Ucapan Terima Kasih (Acknowledgement)}

Tim peneliti mengucapkan terima kasih kepada pihak-pihak terkait yang membantu dalam pelaksanaan penelitian ini, diantaranya Lembaga Penelitian dan Pengabdian Masyarakat serta responden dari berbagai profesi yang telah memberikan kontribusi dalam penelitian ini.

\section{REFERENSI}

Andriani, I. (2009). Desain ruang kerja, privasi, dan tekanan. Jurnal Psikologi Universitas Gunadarma, 2(2). 183-190.

Asensio, P. (2003). Color in your home editorial project. HarperCollins International.

Botti-Salitsky, RM. (2017). Programming \& research 'skills and techniques for interior designers. Bloomsbury Inc $2^{\text {nd }}$.

Cunliffe, R. (2000). Tomorrow's office: creating effective and humane interior $1^{\text {st }}$ edition. Taylor \& Francis.

Karlem, M. (2007). Dasar-dasar perencanaan ruang. Erlangga.

Kilmer, R \& Kilmer, WO. (2014). Designing interior $2^{\text {nd }}$ edition. John Wiley \& Sons.

Moore, B. (2004). Interior style how to use color throughout your home. HarperCollins International.

Mungkasa, O. (2020). Bekerja dari rumah (working from home/wfh): Menuju tatanan baru era pandemi covid-19. The Indonesia Journal of Development Planning, 4(2), 127-150.

Purwanto, A. (2020). Studi eksplorasi dampak work from home (wfh) terhadap kinerja guru selama pandemi covid-19. Journal of Education, Psychology and Counselling, 2(1), 92100.

Postel, J. (2012). Furniture design $2^{\text {nd }}$ edition. John Wiley \& Sons.

Suptandar, J. P. (2003). Perancangan tata ruang dalam (desain interior). Universitas Trisakti.

Zimring, C.M. (2013). Post-occupancy evaluation and implicit theory: An overview. In W. F. E. Preiser (Ed.). Building evaluation. Springer. 